Primljen / Received: 14.12.2016. Ispravljen / Corrected: 29.6.2017.

Prihvaćen / Accepted: 4.8.2017.

Dostupno online / Available online: 10.12.2018.

\title{
Ranking conceptual locations for a park- and-ride parking lot using EDAS method
}

Authors:

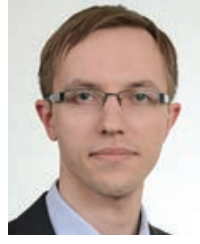

Andrius Barauskas, Msc. CE

Vilnius Gediminas Technical University, Lithuania Department of Roads

andrius.barauskas@vgtu.It

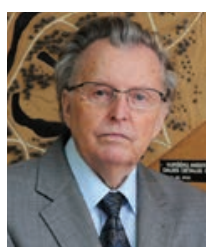

Prof. Konstantinas Jakovlevas-Mateckis, PhD. Arh Vilnius Gediminas Technical University, Lithuania Department of Roads

konstantinas.jakovlevas-mateckis@vgtu.It

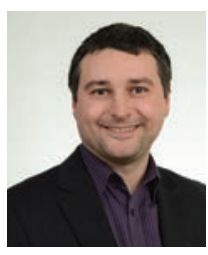

Assoc.Prof. Vytautas Palevičius, PhD. CE Vilnius Gediminas Technical University, Lithuania Department of Roads vytautas.palevicius@vgtu.It

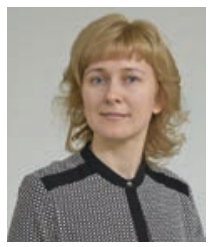

Prof. Jurgita Antuchevičienè, PhD. CE Vilnius Gediminas Technical University, Lithuania Department of Construction Tech. and Management jurgita.antucheviciene@vgtu.It
Andrius Barauskas, Konstantinas Jakovlevas-Mateckis, Vytautas Palevičius, Jurgita Antuchevičienè

Ranking conceptual locations for a park-and-ride parking lot using EDAS method

The decision regarding the location of a Park-and-Ride (P\&R) parking lot must be taken by simultaneously considering economic, social, urban, environmental, and other factors. This task is simplified by selection of three conceptual locations for P\&R parking lots near the Vilnius western bypass. The aim of the paper is to identify key criteria that promote successful functioning of the private and public transport systems, and to rank these conceptual locations using the Evaluation based on Distance from Average Solution (EDAS) multiple-criteria decision-making method.

Key words:

city bypass, Park-and-Ride (P\&R) parking lot, multiple-criteria decision, EDAS

Prethodno priopćenje Andrius Barauskas, Konstantinas Jakovlevas-Mateckis, Vytautas Palevičius, Jurgita Antuchevičienè

\section{Rangiranje idejnih lokacija za Park\&Ride parkirališta pomoću EDAS metode}

Prilikom planiranja lokacije za Park\&Ride (skraćeno P\&R) parkirališta treba istovremeno uzeti u obzir ekonomske, društvene, urbane, okolišne i druge čimbenike. Kako bi se navedena zadaća pojednostavnila, odabrane su tri idejne lokacije za P\&R parkirališta u blizini zapadne obilaznice grada Vilniusa (Litva). Cilj je ovog rada odrediti ključne kriterije koji unapređuju uspješno funkcioniranje osobnog i javnog prijevoza te rangirati navedene idejne lokacije primjenom višekriterijske metode odlučivanja EDAS (engl. Evaluation based on Distance from Average Solution).

Ključne riječi:

gradska obilaznica, Park\&Ride parkiralište, višekriterijsko odlučivanje, EDAS

Vorherige Mitteilung

Andrius Barauskas, Konstantinas Jakovlevas-Mateckis, Vytautas Palevičius, Jurgita Antuchevičienè

\section{Anordnung der Design-Standorte für Park\&Ride Parkplätze mithilfe der} EDAS-Methode

Bei der Planung des Standorts für Park\&Ride-Parkplätze (kurz P\&R) sollten gleichzeitig die wirtschaftlichen, sozialen, urbanen, ökologischen und andere Faktoren berücksichtigt werden. Um die genannte Aufgabe zu vereinfachen, wurden drei Design-Standorte für P\&R-Parkplätze in der Nähe der westlichen Umgehung der Stadt Vilnius (Litauen) ausgesucht. Das Ziel dieser Abhandlung ist es, Schlüsselkriterien festzulegen, welche das erfolgreiche Funktionieren von Personen- und öffentlichen Verkehrsmitteln verbessern, wie auch um die erwähnten Design-Standorte durch Anwendung der Multi-Kriterien-Entscheidungsmethode EDAS (engl. Evaluation based on Distance from Average Solution) zu ordnen.

Schlüsselwörter:

Stadtumgehung, Park\&Ride-Parkplätze, Multi-Kriterien-Entscheidung, EDAS 


\section{Introduction}

The recent decade saw a high increase in concerns regarding sustainability of transport. As congestion ranks among the most important problems in medium-sized and large cities [1], various means of mass transit, and especially the Park-and-Ride (P\&R) system, have become one of the most discussed sustainable transport alternatives. Park and ride facilities offer the possibility to access a city centre using public transport. It can be a bus, bus rapid transit, rail, or metro. It is regarded as a new travel mode that attracts private car users to use public transport. The P\&R system can be explained in very simple terms: people use their private cars to drive from their place of residence to a P\&R facility, park there, switch to public transport, and reach their destination. This system allows users to avoid highly congested city areas, and to use private car in the least congested areas only, which results in travel time and cost savings. Besides, the city becomes less congested as transit systems become more popular. In their research covering 25 European cities, Dutch researchers confirm that the development of the P\&R option has reduced congestion and air pollution [2].

Locating P\&R facilities is a complex task involving multiple factors, such as characteristics of a P\&R facility, the level of service (LOS) of the transit system, the expected demand and market potential, the impact on the surrounding area, the transport policy (tolls, restricted private car areas, etc.), and user benefits and costs. Also, urban areas have limited location alternatives.

The research reported in this paper relies on the expert-based Kendall evaluation for identifying priority of the most important criteria that determine the P\&R location near city bypasses/ ring roads, and uses the multiple-criteria decision-making methodology for suggesting the ranking of potential locations for the P\&R parking lot.

This paper is organised as follows. Section 2 discusses literature on different approaches for finding an optimum location for a P\&R facility. Section 3 gives an overview of well-known P\&R facilities located near city bypasses $\backslash$ ring roads. The research methodology is described in Section 4. Section 5 presents the multiple-criteria evaluation of parking lot locations. Finally, research conclusions are discussed in Section 6.

\section{Literature review}

Many researchers have studied decisions determining P\&R locations and have identified various possible approaches in the process. for example, Horner and Grubesic [3] suggest the Geographic Information System (GIS), Faghri et al. [4] propose an expert system, Abdul Hamid et al. [5] use the demand analysis, and Farhan and Murray [6] offer optimisation formulations. In addition, Holguí n-Veras et al. [7] use the maximization of potential demand, Khakbaz et al. [8], Horner and Groves [9] place emphasis on maximization of flow capture, while Wang et al. [10] focus on profit maximization and social cost minimization. However, one of the most important tasks in determining P\&R locations is to find the most rational way to maximize potential benefits of the P\&R system [11-13].

$P \& R$ is a part of the mode choice, and it is one of the most complex decision processes in demand modelling, as it depends on the attributes of travellers, trip characteristics, and performance of competing modes [14]. A lot of P\&R location guidelines, formulated based on case studies, are also available, but their suggestions are rather confusing and inconsistent. It is therefore not surprising that most $P \& R$ facilities are inadequately positioned [2].

Also, all these location-based methods lead to a potentially large number of alternative sites. Having in mind that in most cases the public sector investment in P\&R facilities is relatively restricted, it is better to use practical rules to make location decisions. It appears that the expert-based method is the most suitable. It is relatively fast and accurate compared to other methods. Farhan and Murray [6] highlight at least three important concerns: user coverage, the effect of existing facilities, and closeness to major roadways. Based on location criterion, Mingardo [15] distinguishes three categories of P\&R:

- Remote P\&R, which aim to intercept drivers at the beginning of their commutes, usually located in suburban areas near user homes.

- Peripheral P\&R, which aim to intercept drivers just before their final destination, usually located on the urban periphery. This model is typical of the UK and the US.

- Local P\&R, which aim to intercept drivers somewhere along their trip, usually located along main transport corridors.

City bypasses/ring roads are common locations of P\&R parking lots. Because city bypasses are located outside of a city and act as borders between uncongested and congested roads, they are in a perfect location to intercept drivers who want to access or leave the city quickly and without any stress.

In this research, the authors consider the most important criteria that determine the location for a P\&R parking lot near city bypasses/ring roads. The research is based on the idea that a group of experts evaluates all the criteria, after which the results are processed and are then used for multiple criteria decision-making.

\section{Overview of foreign practice}

Good practice can be found in the UK, where the P\&R system has been in use for more than half a century, and where new P\&R parking lots are still being created. A park-and-ride solution was first applied some 50 years ago by small historic cities. Back then, the UK saw a significant growth in the busbased P\&R schemes. Now, there are over 130 interchange sites operating and serving more than 60 towns and cities across the Great Britain. All P\&R sites share some similarities. First, they are implemented by local authorities and are considered to be a part of local transport strategies. Second, sites are found around four $\mathrm{km}$ from the urban core, close to main access corridors. Third, sites are designed to attract the motorists with pleasant 
surroundings and often on-site facilities, such as waiting areas. Fourth, high-quality buses operate at high frequency, generally every 8 and 15 minutes in peak periods. Finally, only one or two stops are usually made to minimise journey time [16].

The UK started experimenting with P\&R facilities since the 1960s. The majority of P\&R schemes failed. Success was enjoyed mostly by historic cities, such as Bath, Chester, Shrewsbury, and Oxford which, by their nature, had constrained opportunities for road access and parking development in city centres [17]. Parking lots were usually located in urban periphery and corresponded to the Mingardo's second category of the P\&R location.

There are six P\&R sites in Oxford: four of them are located around the Oxford ring road, one of them is at a close distance, and the last one is far from the Oxford ring road, near the Bicester Shopping Village, which is not included in our research as a ring road $P \& R$. The remaining five locations of $P \& R$ parking lots are presented in Figure 1.

The Thornhill P\&R is located off the A40 and M40, to the east of Oxford, about 15 minutes away from the Oxford city centre. The Redbridge $P \& R$ is located in the south, near the $A 34$, about 10 minutes from the city centre. Seacourt P\&R is located off the $A 420$ from Swindon and Bath, to the west of Oxford on the Botley Road. The Pear Tree P\&R is located in the north of Oxford accessed from the $A 40, A 4260, A 34$ and M40. It is 12 minutes away from the city centre. The Water Eaton P\&R is located to the north of Oxford, 12 minutes away from the town, and can be accessed from the A40, A34 and A4260. They provide regular bus services to the city centre, and from some car parks, there are bus routes to hospitals.



Figure 1. Locations of P\&R parking lots in Oxford

The website of the Oxfordshire county council [18] shows realtime occupancy of Oxford's P\&R parking lots. Based on this information, data were gathered to make the diagram of the daily use of P\&R parking lots during workdays. The occupancy of P\&R parking lots was registered on 7 June 2016 (Tuesday), from 5:30 to 21:30. The data are presented in Figure 2.

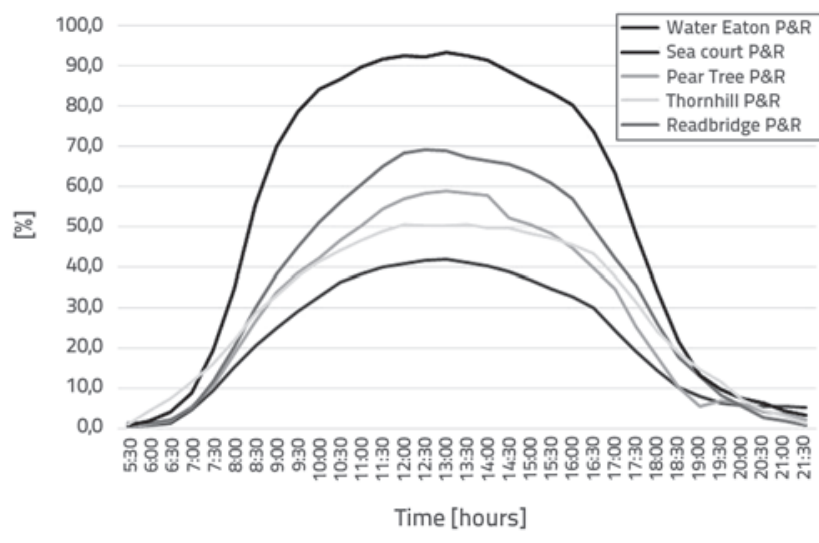

Figure 2. Average use of P\&R during workdays

The most successful P\&R site is Seacourt with the occupancy ratio of $93 \%$. There are multiple factors that could determine these good results, and one of them could be that P\&R sites located on the inner ring road tend to get better results than others as they represent the breaking points. At these breaking points, the private transport starts to lose its benefits to public transport. In other words, the private transport becomes unattractive as the travel speed decreases compared to that of the public transport; besides, fewer parking places are available. It was established that P\&R parking lots located near city ring roads or bypasses definitely bring good results in terms of the occupancy ratio.

\section{Evaluation of development of P\&R parking lots near a city bypass: the multiple-criteria decision-making method}

Multi-criteria decision-making methods are designed for complex tasks. Such methods are helpful when there is a need to combine objective information with subjective preferences, and when multiple decision makers are to be involved.

There are two categories of evaluation methods: quantitative and qualitative. Quantitative analysis methods require large quantities of reliable data that are, in most cases, hard or even impossible to obtain due to various reasons. A qualitative analysis is based on expert judgement. In Vilnius, obtaining large quantities of data is a difficult task. Also, the number of alternatives is rather limited. Multi-criteria methods cope very well with cases of this kind.

Multiple criteria problems can be solved using various single decision-making methods, both in crisp form or with fuzzy numbers [19-21]. A combination of several methods [22] or hybrid methods can also be used [23]. One of the most common complex decision-making methods is the Analytic Hierarchy Process (AHP). This method was adopted by Lanović and Krasić in their P\&R facility planning work [24]. In this research, the authors use a new method introduced in 2015 by Keshavarz Ghorabaee et al. This new method is known as the Evaluation based on Distance from Average Solution (EDAS) [25]. The 
EDAS method uses an average solution for appraising the alternatives, considering the positive distance from the average, and the negative distance from the average. This method is very useful when conflicting criteria have to be considered. As has been found and claimed by the authors of the method [25], the EDAS method is stable when various criteria weights are used, and is consistent with other methods. In addition, the simplicity and faster computation are advantages of the proposed method, especially as these advantages do not affect accuracy of calculation. The steps for using the proposed method are presented as follows [25]:

STEP 1: Construction of the decision-making matrix $(X)$. The method evaluates the decision matrix $X$, which refers to $n$ alternatives and $m$ criteria:

$X=\left[X_{i j}\right]_{n \times m}=\left[\begin{array}{cccc}X_{11} & X_{12} & \cdots & X_{1 m} \\ X_{21} & X_{22} & \cdots & X_{2 m} \\ \vdots & \vdots & \ddots & \vdots \\ X_{n 1} & X_{n 2} & \cdots & X_{n m}\end{array}\right]$

where $X_{i j}$ is the performance of the $i$-th alternative with regard to the $j$-th criterion.

STEP 2: Determination of average solution according to all criteria:

$A V=\left[A V_{j}\right]_{1 \times m}$

where

$A V_{j}=\frac{\sum_{i=1}^{n} X_{i j}}{n}$

STEP 3: Calculation of positive distance from the average (PDA) and negative distance from the average (NDA):

$$
\begin{aligned}
& P D A=\left[P D A_{i j}\right]_{n \times m} \\
& N D A=\left[N D A_{i j}\right]_{n \times m}
\end{aligned}
$$

Table 1. Criteria promoting successful work of the private and public transport system near city bypass

\begin{tabular}{|c|l|}
\hline Criterion & Description of criteria \\
\hline$x_{1}$ & Price of the P\&R parking lot (buildings, parking lot, infrastructure, etc.) including price of land \\
\hline$x_{2}$ & Frequency of public transport at the P\&R parking lot \\
\hline$x_{3}$ & Traffic flow volume in the bypass beside Park \& Ride parking lot \\
\hline$x_{4}$ & Distance to the city centre from the P\&R parking lot \\
\hline$x_{5}$ & Total price when using the combination of the P\&R parking lot and public transport \\
\hline$x_{6}$ & Private investments in the Park \& Ride parking lot (shopping malls, services, etc.) \\
\hline$x_{7}$ & Promotion by public institutions to use the Park \& Ride parking lot when taking intercity travels \\
\hline$x_{8}$ & $\begin{array}{l}\text { Benefits of public transport compared to the use of private cars (faster, more comfortable, no need to search for a parking space, } \\
\text { etc.) }\end{array}$ \\
\hline$x_{9}$ & Information system at the P\&R parking lot (number of free spaces, schedule of public transport, other information) \\
\hline$x_{10}$ & Free parking lot places at the city centre \\
\hline
\end{tabular}

If $j$-th criterion is beneficial:

$$
\begin{aligned}
P D A_{i j} & =\frac{\max \left(0,\left(X_{i j}-A V_{j}\right)\right)}{A V_{j}} \\
N D A_{i j} & =\frac{\max \left(0,\left(A V_{j}-X_{i j}\right)\right)}{A V_{j}}
\end{aligned}
$$

If $j$-th criterion is non-beneficial:

$$
\begin{aligned}
P D A_{i j} & =\frac{\max \left(0,\left(A V_{j}-X_{i j}\right)\right)}{A V_{j}} \\
N D A_{i j} & =\frac{\max \left(0,\left(X_{i j}-A V_{j}\right)\right)}{A V_{j}}
\end{aligned}
$$

STEP 4: Determination of weighted sum for PDA and NDA:

$S P_{i}=\sum_{j=1}^{m} w_{j} P D A_{i j}$

$S N_{i}=\sum_{j=1}^{m} w_{j} N D A_{i j}$

where $w_{j}$ is the weight of the $j$-th criterion

STEP 5: Normalization of SP and SN:

$N S P_{i}=\frac{S P_{i}}{\max _{i}\left(S P_{i}\right)}$

$N S N_{i}=1-\frac{S N_{i}}{\max _{i}\left(S N_{i}\right)}$

STEP 6: Calculation of appraisal score (AS):

where $0 \leq A S_{i} \leq 1$
$A S_{i}=\frac{1}{2}\left(N S P_{i}+N S N_{i}\right)$

)


STEP 7: Ranking alternatives by decreasing values of appraisal score (AS).

The alternative with the highest appraisal score is the best choice. To use the EDAS multi-criteria decision-making method, necessary tasks are completed in the next section, and the evaluation results are presented in the final subsection.

\section{Multiple-criteria evaluation}

\subsection{Sampling criteria for selecting P\&R parking lot location near city bypass}

Several criteria of crucial significance for defining location of the P\&R parking lot near the city bypass are determined in the first phase. Various criteria such as the economics, urban planning, social, environmental, and other aspects, are considered in this phase. The final list of criteria was created by the group of three experts in consultation with the local community and authorities concerned with this development. The criteria are presented in Table 1 . Out of these ten criteria, six are quantitative $\left(x_{1-5^{\prime}} x_{10}\right)$ and the remaining four are qualitative $\left(\mathrm{x}_{6-9}\right)$. Qualitative criteria are estimated using the Likert item scale (Table 2). Detailed information about the criteria:

- $\quad x_{1}$ : land price $\left(€ / 1000 \mathrm{~m}^{2}\right)$ and construction cost $\left(€ / 1000 \mathrm{~m}^{2}\right)$ [thousands of $€$ ], average prices in 2016, considered for the conceptual locations of the P\&R parking lot

- $x_{2}$ - number of public transport routes near the P\&R parking lot during the peak hour [number of routes/peak hour]

- $\quad \mathrm{x}_{3}$ : traffic flow volume at the bypass next to the Park \& Ride parking lot (at the moment, some parts of the Vilnius western bypass are not finished, therefore, the modelled traffic volume data were used) [veh/peak hour]

- $x_{4}$ : distance to the city centre (central post office) from the $P \& R$ parking lot $[\mathrm{km}]$

- $\quad x_{5}$ : total price when using the combination of the P\&R parking lot and public transport $[€]$, assuming that leaving a car at the P\&R parking lot costs EUR 2 for 11 hours and the public transport ticket is EUR 1;

In the $1^{\text {st }}$ and $2^{\text {nd }}$ concept, P\&R parking lots are considered to be free for of charge, and so the public transport ticket is charged only, and the $3^{\text {rd }}$ concept is fully priced, i.e. EUR 2 for a parking space and EUR 1 for public transport (this price policy is inversely proportional to the price of each concept of the P\&R parking lot, including the price of the land). $\mathrm{x}_{6}$ : possible private investments in the Park \& Ride parking lot (shopping malls, services, etc.), attractiveness levels according to the Vilnius Master Plan [1 - very unattractive, 2 - unattractive, 3 - neutral, 4 - attractive, 5 - very attractive]

$\mathrm{x}_{7}$ : promotion by public institutions of the use of the Park \& Ride parking lot when taking intercity travels from the largest Lithuanian cities based on the main and shortest route [1 - very weak, 2 weak, 3 - medium, 4 - strong, 5 - very strong], assuming that the conceptual $P \& R$ parking lots located near the main roads connecting major Lithuania cities would be more attractive for users coming from other major cities (the $3^{\text {rd }}$ concept of the P\&R parking lot is the most attractive because it is located near the road connecting the main Lithuanian cities, i.e. Klaipeda, Kaunas and Vilnius; the $1^{\text {st }}$ concept is less attractive than the $3^{\text {rd }}$ as it connects Šiauliai, Panevėžys, and Vilnius; and the $2^{\text {nd }}$ concept does not connect any of the main cities, and so it is considered unattractive) $\mathrm{x}_{8}$ : benefits of the public transport compared to the use of a private car (faster, more comfortable, no need to search for a parking space, etc.) [1 - very weak, 2 - weak, 3 - medium, 4 - strong, 5 - very strong], assuming that the best results are delivered by the fastest public transport arteries, - the $1^{\text {st }}$ and $2^{\text {nd }}$ concepts for the location of the P\&R parking lot are on rapid public transport arteries; and the $3^{\text {rd }}$ one is on an average speed artery $\mathrm{x}_{\mathrm{g}}$ :information system at the P\&R parking lot, and attractiveness of its location from the visibility perspective from the bypass or/and the main road [ 1 - very unattractive, 2 - unattractive, 3 - neutral, 4 attractive, 5 - very attractive], all locations are considered attractive in terms of visibility from the bypass or/and the main road $\mathrm{x}_{10}$ : free parking lot places driving to the city centre [the number], assuming that the lack of free parking at the city centre would encourage choosing the P\&R instead.

Table 2. Likert item scale

\begin{tabular}{|c|c|c|}
\hline \multirow{2}{*}{ Scale } & \multicolumn{2}{|c|}{ Criteria } \\
\cline { 2 - 3 } & $\boldsymbol{x}_{\mathbf{7}}$ & $\boldsymbol{x}_{\mathbf{6}^{\prime}} \boldsymbol{x}_{\boldsymbol{g}^{\prime}} \boldsymbol{x}_{\mathbf{9}}$ \\
\hline 1 & Very weak & Very unattractive \\
\hline 2 & Weak & Unattractive \\
\hline 3 & Medium & Neutral \\
\hline 4 & Strong & Attractive \\
\hline 5 & Very strong & Very attractive \\
\hline
\end{tabular}

\subsection{Determining significance of criteria for location of \&R parking lot near city bypass}

The final ten criteria were presented to experts. The expert group consisted of 21 experts, out of which six from Slovenia and the remaining ones from Lithuania. The experts were construction engineering, transport engineering, civil engineering, road engineering, energy and environmental engineering scientists and specialists. They were selected according to their work experience (no less than ten years), position at their workplace (division level and higher), and degree (Master's degree and higher).

A variety of methods have been developed for expert evaluations. The criteria ranking method, proposed by Kendall [26], ranks among the most popular methods. Ranking is a procedure in which an expert gives the highest ranking and the score of one to the most important criteria; the second highest criteria are given the score of 2 ; the third the score of 3 , and so on. This method is very simple and can easily be applied in practical calculations [27]. 
According to Kendall, the concordance coefficient is associated with ratings of all respondents or experts for criteria in respect

$R_{j}=\sum_{i=1}^{n} R_{i j} \mathrm{j}=1,2, \ldots, \mathrm{m}$

and the average for criteria $\bar{R}_{j}$ is obtained by dividing the sum of all ranks by the number of criteria:

$\bar{R}_{j}=\frac{R_{j}}{m}$

where: $R_{i j}$ - the $i$-th expert for the $j$-th criteria given rank, $n$ - the number of experts $(i=1,2, \ldots, n), m$ - the number of criteria $(j$ $=1,2, \ldots, m)$

Relative significance of criteria is calculated as follows:

$w_{j}=\frac{\bar{R}_{j}}{\sum_{j=1}^{m} \bar{R}_{j}}$

The concordance coefficient $W$ is calculated according to the formula:

$W=\frac{12 S}{n^{2}\left(m^{3}-m\right)}$

The sum of the square $R_{j}$ of the deviation from the total average $\bar{R}_{j}$ of values $S$ is defined by the formula:

$S=\sum_{i=1}^{m}\left(R_{j}-\bar{R}_{j}\right)^{2}$

The significance of the concordance coefficient and the compatibility of the group of criteria by expert evaluation is determined by $\chi^{2}$ :

$\chi^{2}=\frac{12 S}{n m(m+1)}$

\begin{tabular}{|c|l|}
\hline Criterion & Description of a criterion \\
\hline$x_{1}$ & Price of the P\&R parking lot with price of land \\
\hline$x_{2}$ & Frequency of public transport at the P\&R parking lot \\
\hline$x_{3}$ & $\begin{array}{l}\text { Traffic flow volume in the bypass beside Park \& Ride } \\
\text { parking lot }\end{array}$ \\
\hline$x_{4}$ & Distance to the city centre from the P\&R parking lot \\
\hline$x_{5}$ & $\begin{array}{l}\text { The total price when using the combination of the P\&R } \\
\text { parking lot and public transport }\end{array}$ \\
\hline$x_{6}$ & Private investments in the Park \& Ride parking lot \\
\hline$x_{7}$ & $\begin{array}{l}\text { Promotion by public institutions to use the Park \& Ride } \\
\text { parking lot when taking intercity travels }\end{array}$ \\
\hline$x_{8}$ & $\begin{array}{l}\text { Benefits of the public transport compared to the use of a } \\
\text { private car }\end{array}$ \\
\hline$x_{9}$ & Information system at the P\&R parking lot \\
\hline$x_{10}$ & Free parking lot places at the city centre \\
\hline
\end{tabular}

The minimum value of the concordance coefficient $W_{\min }$ is calculated using the formula:

$W_{\min }=\frac{\chi_{v, \alpha}^{2}}{n(m-1)}$

where: $\chi_{v, \alpha}^{2}$ is the critical Pearson statistics, the value of which is found in Table [26], taking into account the degree of freedom $v=m-1$ and the level of significance $\alpha$. The concordance coefficient $W=0.404$ was calculated. Based on Eq. (20), the calculated value $\chi^{2}=90.81$ exceeds the critical value $\chi_{v, \alpha}^{2}$ with the significance level amounting to $\alpha=0.05$. Results obtained by calculation show that expert judgements are consistent.

The expert survey analysis showed that the first criterion (the highest importance criterion) was "Frequency of public transport at the Park \& Ride parking lot" (0.150). The second most important criterion was "Benefits of the public transport compared to the use of a private car (faster, more comfortable, no need to search for a parking space, etc.)" (0.136), and the third one was "Free parking lot places at the city centre" (0.129). The least important criteria were: "Private investments in the Park \& Ride parking lot (shopping malls, services, etc.)" (0.046) and "Promotion by public institutions to use the Park \& Ride parking lot when taking intercity travels" (0.061). All criteria weights are presented in Figure 3.

\subsection{Alternatives and criteria for solving problem of P\&R location near city bypass}

Three conceptual alternatives for the location of the P\&R parking lot near the Vilnius western bypass have been chosen (Figure 4). The first conceptual location is near the main road A2 (Ukmerges Street) and at the end of the western bypass. The second conceptual location is at the intersection of Pilaites Avenue and the western bypass, and the third one - at the intersection of Oslo

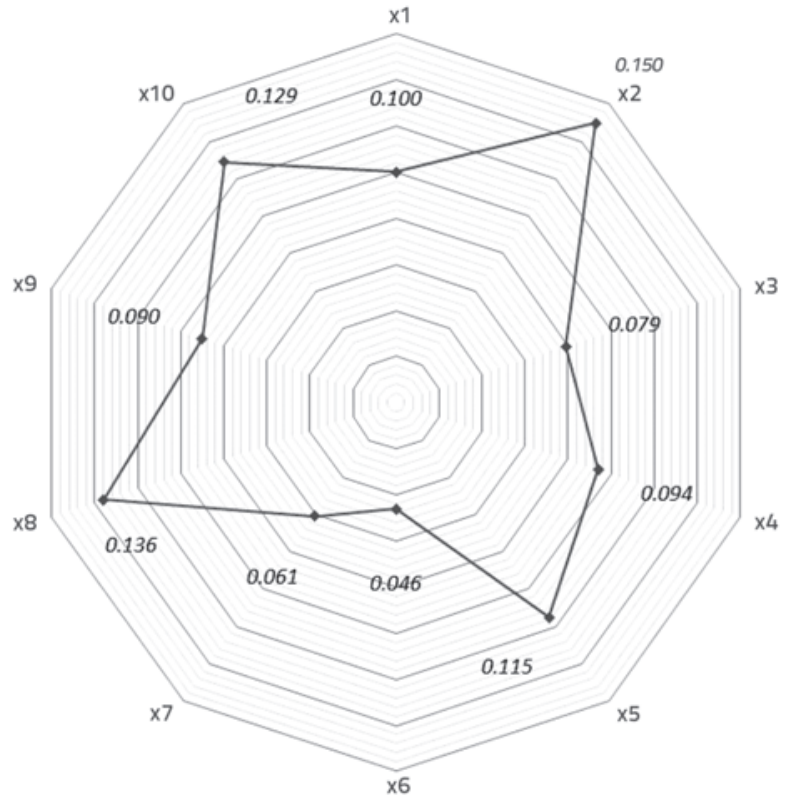

Figure 3. Significance of criteria for developing the P\&R parking lot near the western bypass 


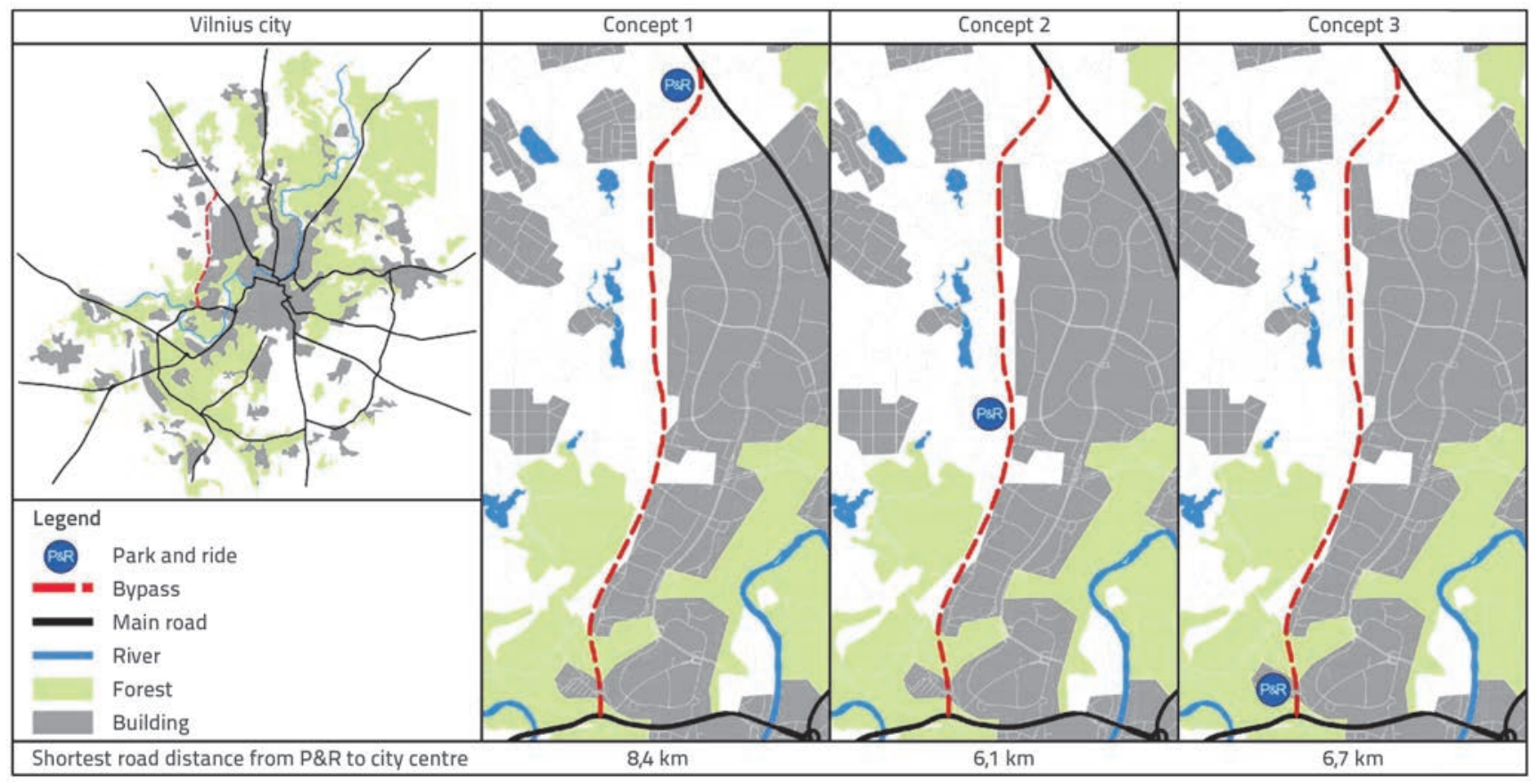

Figure 4. Conceptual places for P\&R parking lot near Vilnius western bypass

Table 3. Criteria for comparison of P\&R parking lot alternatives

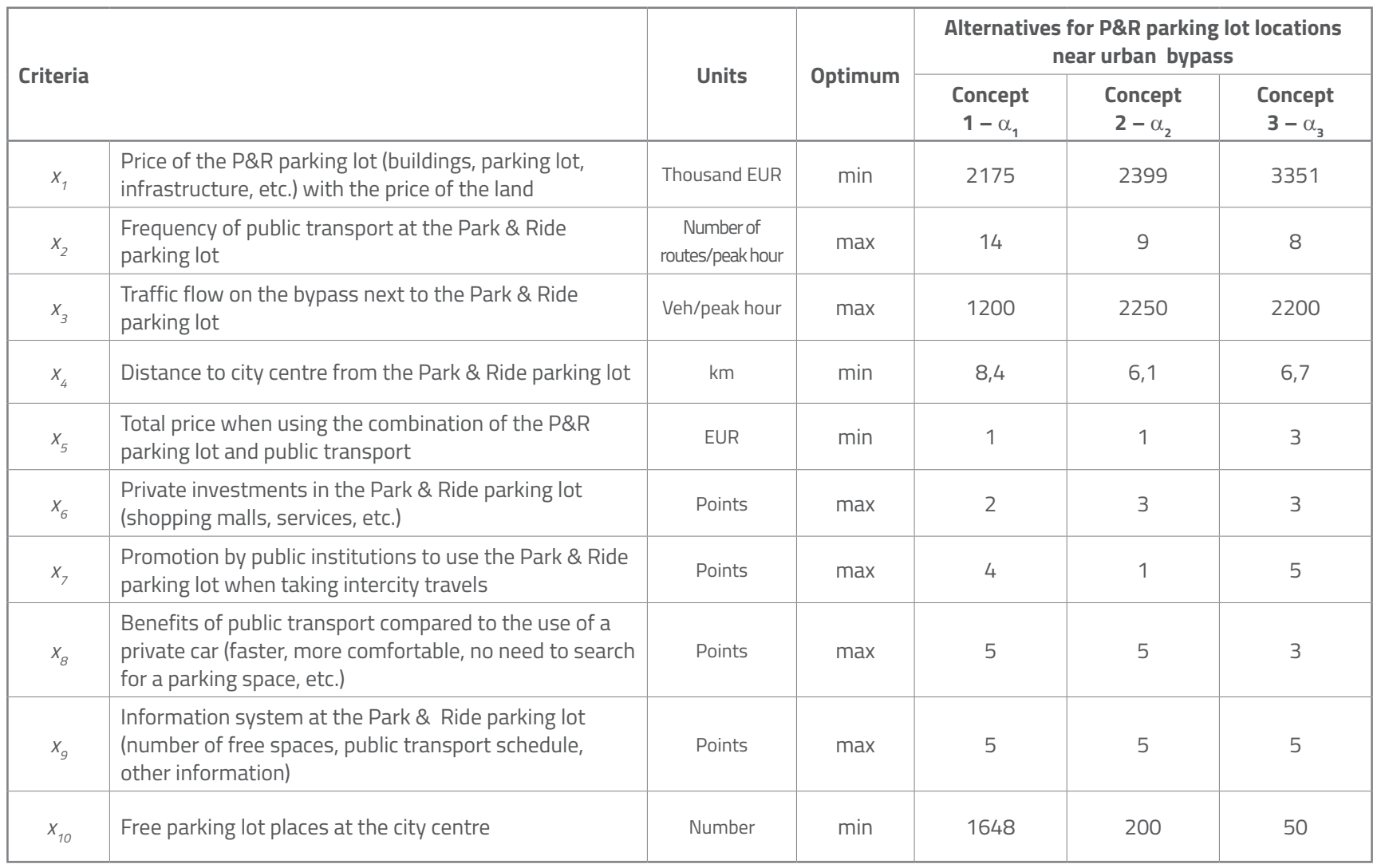

Street and the beginning of the western bypass. These locations are considered to be the most suitable for P\&R parking lots near the city bypass. The criteria are evaluated using quantitative $\left(\mathrm{x}_{1^{\prime}}\right.$ $\left.\mathrm{x}_{2^{\prime}}, \mathrm{x}_{3^{\prime}} \mathrm{x}_{4^{\prime}}, \mathrm{x}_{5^{\prime}} \mathrm{x}_{10}\right)$ and qualitative $\left(\mathrm{x}_{6^{\prime}}, \mathrm{x}_{7^{\prime}}, \mathrm{x}_{8^{\prime}} \mathrm{x}_{9}\right)$ measures. Qualitative measures are evaluated using the five-level Likert item scale. The criteria and values are presented in Table 3. 
Table 4. EDAS results (Part 1)

\begin{tabular}{|c|c|c|c|c|c|c|c|c|c|c|c|c|c|c|}
\hline & AV & $\operatorname{PDA} \alpha_{1}$ & PDA $\alpha_{2}$ & $\operatorname{PDA} \alpha_{3}$ & NDA $\alpha_{1}$ & NDA $\alpha_{2}$ & NDA $\alpha_{3}$ & $w$ & $\mathbf{S P} \alpha_{1}$ & $\mathbf{S P} \alpha_{2}$ & $\mathbf{S P} \alpha_{3}$ & SN $\alpha_{1}$ & SN $\alpha_{2}$ & $\mathbf{S N} \alpha_{3}$ \\
\hline$x_{1}$ & 2641.667 & 0.177 & 0.092 & 0.000 & 0.000 & 0.000 & 0.269 & 0.100 & 0.018 & 0.009 & 0.000 & 0.000 & 0.000 & 0.027 \\
\hline$x_{2}$ & 10.333 & 0.355 & 0.000 & 0.000 & 0.000 & 0.129 & 0.226 & 0.150 & 0.053 & 0.000 & 0.000 & 0.000 & 0.019 & 0.034 \\
\hline$x_{3}$ & 1883.333 & 0.000 & 0.195 & 0.168 & 0.363 & 0.000 & 0.000 & 0.079 & 0.000 & 0.015 & 0.013 & 0.029 & 0.000 & 0.000 \\
\hline$x_{4}$ & 7.067 & 0.000 & 0.137 & 0.052 & 0.189 & 0.000 & 0.000 & 0.094 & 0.000 & 0.013 & 0.005 & 0.018 & 0.000 & 0.000 \\
\hline$x_{5}$ & 1.667 & 0.400 & 0.400 & 0.000 & 0.000 & 0.000 & 0.800 & 0.115 & 0.046 & 0.046 & 0.000 & 0.000 & 0.000 & 0.092 \\
\hline$x_{6}$ & 2.667 & 0.000 & 0.125 & 0.125 & 0.250 & 0.000 & 0.000 & 0.046 & 0.000 & 0.006 & 0.006 & 0.012 & 0.000 & 0.000 \\
\hline$x_{7}$ & 3.333 & 0.200 & 0.000 & 0.500 & 0.000 & 0.700 & 0.000 & 0.061 & 0.012 & 0.000 & 0.031 & 0.000 & 0.043 & 0.000 \\
\hline$x_{8}$ & 4.333 & 0.154 & 0.154 & 0.000 & 0.000 & 0.000 & 0.308 & 0.136 & 0.021 & 0.021 & 0.000 & 0.000 & 0.000 & 0.042 \\
\hline$x_{9}$ & 5.000 & 0.000 & 0.000 & 0.000 & 0.000 & 0.000 & 0.000 & 0.090 & 0.000 & 0.000 & 0.000 & 0.000 & 0.000 & 0.000 \\
\hline$x_{10}$ & 632.667 & 0.000 & 0.684 & 0.921 & 1.605 & 0.000 & 0.000 & 0.129 & 0.000 & 0.088 & 0.119 & 0.207 & 0.000 & 0.000 \\
\hline
\end{tabular}

Table 5. EDAS Results (Part 2)

\begin{tabular}{|c|c|c|c|c|c|c|}
\hline P\&R parking lot alternative & SP & NSP & SN & NSN & AS & Ranking \\
\hline$\alpha_{1}$ & 0.150 & 0.756 & 0.265 & 0 & 0.378 & 3 \\
\hline$\alpha_{2}$ & 0.198 & 1 & 0.062 & 0.766 & 0.883 & 1 \\
\hline$\alpha_{3}$ & 0.173 & 0.873 & 0.195 & 0.266 & 0.569 & 2 \\
\hline
\end{tabular}

\subsection{Calculation results}

According to calculation results received by applying the EDAS method (Eq. 1-14), the conceptual alternatives for the P\&R parking lot are ranked as follows: $\alpha_{2}$ first place, $\alpha_{3}-$ second place, and $\alpha_{1}$ - third place (Table 4 and Table 5).

In this case study, the best alternative is the second one (conceptual location of the P\&R parking lot, at the intersection of Pilaites Avenue and the Western Bypass) and the least favourable alternative is the first one (conceptual location of the P\&R parking lot, near the main road A2 (Ukmergès Street) and the end of the western bypass). The best alternative is way ahead of the other two suggested conceptual locations of the P\&R parking lot, as appraisal scores were $0.833>0.569>0.378$.

\section{Conclusions}

The analysis of scientific literature shows that different approaches are currently used for finding the most suitable locations for P\&R parking lots. However, most of them could lead to a potentially large number of alternative locations. Practical rules, working examples of P\&R parking lots, expert experience and knowledge, and multi-criteria approach, could be adopted to make a quick decision regarding the location of a P\&R parking lot. A multiple criteria approach is proposed in the paper for analysing the problem regarding location of a P\&R parking lot. The problem was evaluated using the multiple-criteria decisionmaking method EDAS to rank conceptual locations for P\&R parking lots, as suggested by experts. The results show that this method for the development of P\&R parking lots is easy to perform, does not require a lot of hardly accessible data, and could be easily adopted in other cities despite the differences in size, sprawl, population, or transport systems. The most import guidelines for applying this method involve the use of practical rules for selecting locations for a P\&R parking lot, collection of main criteria regarding these concept locations, and processing all data by means of the multiple criteria approach.

The analysis of the expert survey shows that the most important criterion was "Frequency of public transport at the Park \& Ride parking lot" (0.150), the second important criterion was "Benefits of the public transport compared to the use of a private car (faster, more comfortable, no need to search for a parking space, etc.)" (0.136), and the third one was "Free parking lot places at the city centre" (0.129). It is clear that, to be attractive to its users, the transit system must offer better quality than that offered by a private car, and the city must be unattractive to private cars. To increase the modal split of the transit system, these main criteria must be considered during development of the urban transport system, starting from the political level to engineering.

In the case study, conceptual locations/alternatives of the P\&R parking lot were ranked as follows (starting from the most favourable one): the second concept (at the intersection of Pilaites Avenue and the western bypass), the third concept (at the intersection of Oslo Street and the beginning of the western bypass), the first concept (near the main road A2 (Ukmerges Street) and the end of the western bypass). Appraisal scores (AS) were as follow: 0.883 ( $2^{\text {nd }}$ alternative), 0.569 ( $3^{\text {rd }}$ alternative), and 0.378 ( $1^{\text {st }}$ alternative). A large difference between AS shows that the multiple-criteria approach is much more reliable than the basic expert decision, which was performed in the first place to choose between equally possible conceptual alternatives of the P\&R parking lot near the city bypass. The same concept of the location decision method could be used for solving other urban or transport planning problems involving location decisions. 


\section{REFERENCES}

[1] OECD: Managing Urban Traffic Congestion, OECD Publications, Paris, 2007.

[2] Dickins, I.S.J.: Park and ride facilities on light rail transit systems, Transportation, 18 (1991), pp. 23-36, http://dx.doi.org/10.1007/ bf00150557

[3] Horner, M., Grubesic, T.: A GIS-based planning approach to locating urban rail terminals, Transportation, 28 (2001), pp. 55-77, http:// dx.doi.org/10.1023/A:1005204010958

[4] Faghri, A., Lang, A., Hamad, K., Heck, H.: Integrated knowledgebased geographic information system for determining optimal location of park-and-ride facilities, Journal of Urban Planning and Development, 128 (2002), pp. 18-41, https://doi.org/10.1061/ (ASCE)0733-9488(2002)128:1(18)

[5] Abdul Hamid, N., Mohamad, J., Karim, M.R.: Parking duration of fringe Park-and-Ride users and delineation of stations catchment area: case of the Kuala Lumpur, Journal of the Eastern Asia Society for Transport Studies, 7 (2007), pp. 1296-1310, http://doi. org/10.11175/easts.7.1296

[6] Farhan, B., Murray, A.: Siting Park-and-Ride facilities using a multiobjective spatial optimization model, Computers \& Operations Research, 35 (2008), pp. 445-456, https://doi.org/10.1016/j. cor.2006.03.009

[7] Holguí n-Veras, J., Yushimito, W.F., Aros-Vera, F., Reilly, J.J.: User rationality and optimal park-and-ride location under potential demand maximization, Transport Research Part B: Methodological, 46 (2012), pp. 949-970, http://dx.doi. org/10.1016/j.trb.2012.02.011

[8] Khakbaz, A., Nookabadi, A.S., Shetab-bushehri, S.N.: A Model for locating Park-and-Ride facilities on urban networks based on maximizing flow capture: a case study of Isfahan, Iran, Networks Spatial Economics, 13 (2013), pp. 43-66, http://dx.doi. org/10.1007/s11067-012-9172-4

[9] Horner, M., Groves, S.: Network flow-based strategies for identifying rail park- and-ride facility locations, Socio-Economic Planning Sciences, 41 (2007), pp. 255-268, https://doi. org/10.1016/j.seps.2006.04.001

[10] Wang, J., Yang, H., Lindsey, R.: Locating and pricing park-and-ride facilities in a linear monocentric city with deterministic mode choice, Transportation Research Part B: Methodological, 38 (2004), pp. 709-731, https://doi.org/10.1016/j.trb.2003.10.002

[11] Clayton, W., Ben-Elia, E., Parkhurst, G., Ricci, M.: Where to park? A behavioural comparison of bus Park and Ride and city centre car park usage in Bath, UK, Journal of Transport Geography, 36 (2014), pp. 124-133, http://dx.doi.org/10.1016/j.jtrangeo.2014.03.011

[12] Du, B., Wang, D.Z.W.: Continuum modeling of park-and-ride services considering travel time reliability and heterogeneous commuters - A linear complementarity system approach, Transport Research Part E: Logistics and Transportation, 71 (2014), pp. 58-81, http://dx.doi.org/10.1016/j.tre.2014.08.008
[13] Liu, Z., Meng, Q.: Bus-based park-and-ride system: a stochastic model on multimodal network with congestion pricing schemes, International Journal of Systems Science, 7721 (2012), pp. 1-13, http://dx.doi.org/10.1080/00207721.2012.743617

[14] Ortúzar, J.D., Willumsen, L.G.: Modelling Transport, Fourth edition, John Wiley and Sons, New York, 2011.

[15] Mingardo, G.: Transport and environmental effects of rail-based Park and Ride: Evidence from the Netherlands, Journal of Transport Geography, 30 (2013), pp. 7-16, http://dx.doi.org/10.1016/j. jtrangeo.2013.02.004

[16] Meek, S., Enoch, M., Ison, S.: Advancing the concept of car-bus interchange in the UK, 88th Annual Meeting of the Transportation Research Board, Washington DC, paper 09-0609, 2009.

[17] Meek, S., Ison, S., Enoch, M.: UK local authority attitudes to Park and Ride, Journal of Transport Geography, 18 (2010), pp. 372-381, http://dx.doi.org/10.1016/j.jtrangeo.2009.09.005

[18] Oxfordshire county council. Park and ride car parks, http://voyager. oxfordshire.gov.uk/Carpark.aspx, 07.06.2016.

[19] Mardani, A., Jusoh, A., Nor, K. M. D., Zakwan, N., Valipour, A.: Multiple criteria decision-making techniques and their applications - a review of the literature from 2000 to 2014, Economic ResearchEkonomska Istrazivanja, 28 (2015), pp. 516-571, http://dx.doi.org /10.1080/1331677X.2015.1075139

[20] Mardani, A., Jusoh, A., Zavadskas, E.K.: Fuzzy multiple criteria decision-making techniques and applications - two decades review from 1994 to 2014, Expert Systems with Applications, 42 (2015), pp. 4126-4148, http://dx.doi.org/10.1016/j. eswa.2015.01.003

[21] Antucheviciene, J., Kala, Z., Marzouk, M., Vaidogas, E.R.: Solving civil engineering problems by means of fuzzy and stochastic MCDM methods: current state and future research, Mathematical Problems in Engineering, 2015, Article ID 362579, 16 pages, 2015., http://dx.doi.org/10.1155/2015/362579

[22] Lazauskas, M., Kutut, V., Zavadskas, E.K.: Multicriteria assessment of unfinished construction projects, Gradevinar, 67 (2015), pp. 319-328, http://dx.doi.org/10.14256/JCE.1179.2014

[23] Zavadskas, E.K., Antucheviciene, J., Turskis, Z., Adeli, H.: Hybrid multiple-criteria decision-making methods: a review of applications in engineering, Scientia Iranica, 23 (2016), pp. 1-20.

[24] Lanović, Z., Krasić, D.: Park \& Ride facility planning, GRAĐEVINAR, 65 (2013) 2, pp. 111-121.

[25] Keshavarz Ghorabaee, K., Zavadskas, E.K., Olfat, L., Turskis, Z.: Multi-criteria inventory classification using a new method of Evaluation based on Distance from Average Solution (EDAS), Informatica, 26 (2015), pp. 435-451, http://dx.doi.org/10.15388/ Informatica.2015.57

[26] Kendall, M.: Rank Correlation Methods, Fourth edition, Griffin, London, 1970.

[27] Montgomery, C.D.: Statistical Quality Control: A Modern Introduction. International Student Version, Wiley, Hoboken, 2008. 